\title{
A Case of Head and Neck Mucosa-Associated Lymphoid Tissue Lymphoma Presenting as Progressive Multiple Cranial Nerve Palsy
}

\author{
Daeyeon Kim ${ }^{1}$, Chang Bae Lee ${ }^{1}$, Min Gyoung Pak ${ }^{2}$, and Dong Kun Lee ${ }^{1} \mathbb{D}$ \\ ${ }^{1}$ Departments of Otolaryngology-Head and Neck Surgery, ${ }^{2}$ Pathology, College of Medicine, Dong-A University, Busan, Korea
}

\section{다발성 뇌신경 마비로 진행된 두경부 MALT Lymphoma 1예}

김대연 ${ }^{1} \cdot$ 이창배 ${ }^{1} \cdot$ 박민경 $^{2}$ - 이동근 ${ }^{1}$

동아대학교 의과대학 이비인후-두경부외과학교실, ${ }^{1}$ 병리학교실 ${ }^{2}$

\author{
Received July 9, 2019 \\ Revised August 5, 2019 \\ Accepted August 7, 2019 \\ Address for correspondence \\ Dong Kun Lee, MD, PhD \\ Department of Otolaryngology- \\ Head and Neck Surgery, \\ College of Medicine, \\ Dong-A University, \\ 26 Daesingongwon-ro, Seo-gu, \\ Busan 49201, Korea \\ Tel $+82-51-240-5428$ \\ Fax $+82-51-253-0712$ \\ E-mail chaos001@hanmail.net
}

Lymphoma is a malignant tumor arising from the lymphoid tissue. Chronic inflammation can make lymphocyte accumulation and proliferation in the mucous membrane. Sustained accumulation of these persistent changes in the lymphoid tissues may be responsible for the development of mucosa-associated lymphoid tissue (MALT) lymphoma. Although multiple cranial nerve palsy have been reported in various lymphoma, it has never been reported in MALT lymphoma. A 39-year-old man reported of facial palsy and subsequent vocal fold palsy. MALT lymphoma was diagnosed as involving the parotid gland, nasopharynx, and the skull base. Vocal palsy and facial palsy were successfully recovered after chemotherapy. Korean J Otorhinolaryngol-Head Neck Surg 2019;62(12):755-9

Key Words Cranial nerve · Facial paralysis · MALT lymphoma $\cdot$ Vocal fold palsy.

\section{서 론}

림프 조직은 점막을 가진 기관에서 쉽게 발견된다. 점막 조 직에 만성적 염증반응이 지속되면 림프구의 축적과 증식을 유발하며, 이러한 변화는 점막 연관성 림프조직(mucosa-associated lymphoid tissue, MALT) 림프종 발생의 원인으로 알려져 있다. ${ }^{1-3)}$ 림프종은 위장을 포함한 소화기계와 호흡기 계, 피부 등 림프조직을 다수 포함하는 대부분의 장기에서 호 발할 수 있다. 여러 가지 림프종으로 인해 다발성 뇌신경마비 가 발생한 보고가 일부 있지만, MALT 림프종은 아직 보고된 바 없다. 39세 남자 환자에서 안면마비가 발생하고 다음에 성 대 마비로 진행된 두경부 MALT 림프종을 진단하고 성공적

This is an Open Access article distributed under the terms of the Creative Commons Attribution Non-Commercial License (https://creativecommons.org/licenses/by-nc/4.0) which permits unrestricted non-commercial use, distribution, and reproduction in any medium, provided the original work is properly cited.
으로 치료하여 이에 문헌 고찰과 함께 보고하는 바이다.

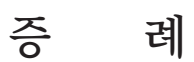

39세 남자 환자가 4개월 전에 양측 귀 통증과 좌측 안면신 경마비로 타 병원을 방문하였다. 신체검사 결과 양측에 삼출 성 중이염이 있었고, 코 점막 전체적으로 가피가 있었다. 측두 골과 얼굴 부위 전산화단층촬영에서는 특이 소견이 없었다. 타 병원에서는 이러한 임상 소견들로 인해 베게너 육아종증 등을 의심하여 비강에서 조직검사를 시행한 결과 염증 소견 만 보여 구강 스테로이드 치료를 2 주간 시행 후 증상의 호전 은 없이 경과 관찰 중이었다. 본원 내원 2주 전부터 좌측 귀와 이하선 통증이 더 악화되었고, 하루 전에는 쉰 목소리가 새로 발생하였다. 과거력에는 특이사항은 없었으며, 신체검사 결과 좌측 이하선 부분에서 경계가 불명확하고 단단한 종물이 약 
2 3 cm 크기로 만져졌다. 신경학적 검사에서 House-brackmann grade 4단계의 좌측 안면마비가 눈과 입에서 관찰되었 고, 다른 이상 소견은 관찰되지 않았다. 고막 내시경 검사에 서 양측 삼출성 중이염 소견이 관찰되었고, 후두 내시경 소견 에서 좌측 성대마비가 관찰되었다(Fig. 1). 좌측 비인두 점막
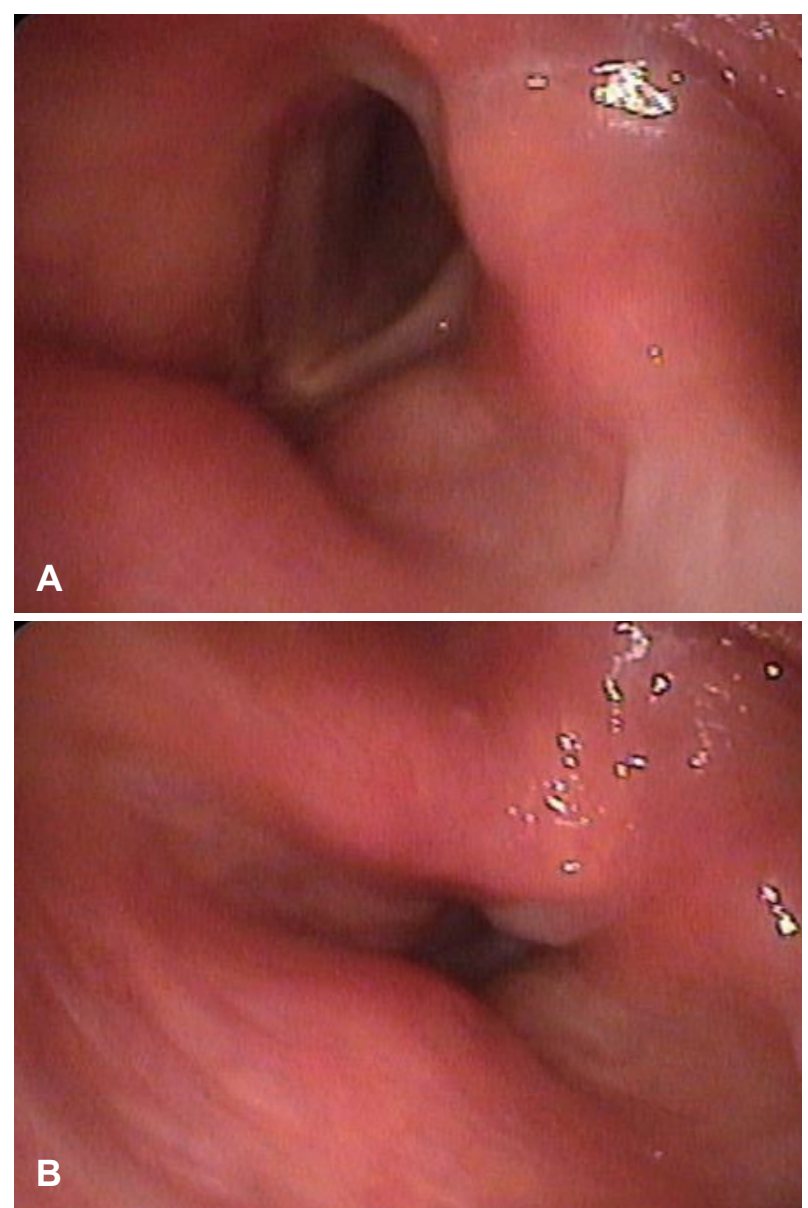

Fig. 1. Laryngoscopic examination reveals left vocal cord palsy. Paramedian type inspiration (A), expiration (B).

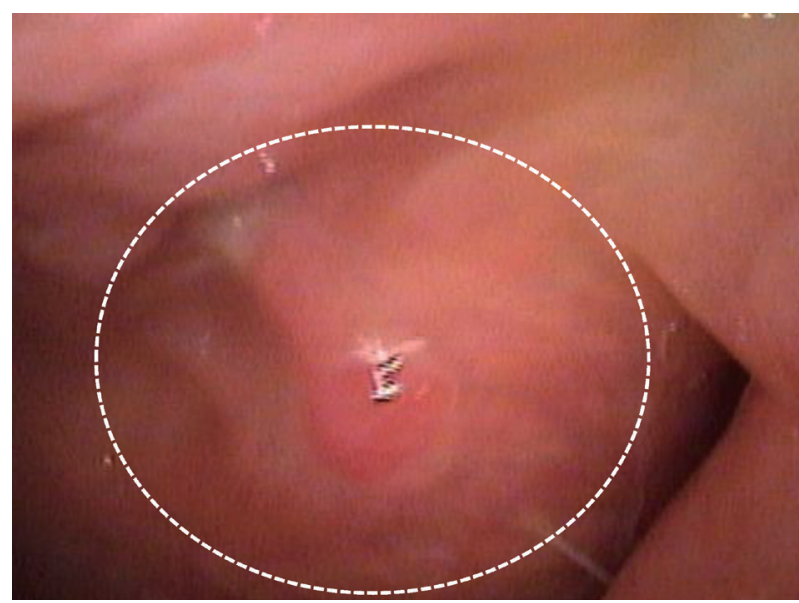

Fig. 2. Endoscopic exam shows nasopharyngeal mucosal swelling (dot-lined circle).
은 뚜렷이 드러나 보이는 종양은 보이지 않았고, 점막하 부종 이 있는 것처럼 관찰되었다(Fig. 2).

목 전산화단층촬영에서 경계가 뚜렷하지 않고 비균질하게 조영이 증강된 병변이 양쪽 비인두, 인두 주위, 좌측 이하선에 서 경정맥공이 있는 좌측 뇌 기저부 그리고 양측 내경동맥과 뇌 실질까지 침윤된 소견이 관찰되었다(Fig. 3). 뇌 자기공명 영상에서 중추신경계의 이상은 발견되지 않았고, T2 강조영 상에서 양쪽 비인두, 인두주위, 좌측 이하선, 좌측 뇌 기저부 에 고강도의 신호를 보였다(Fig. 4). 우선 병리학적 진단을 위
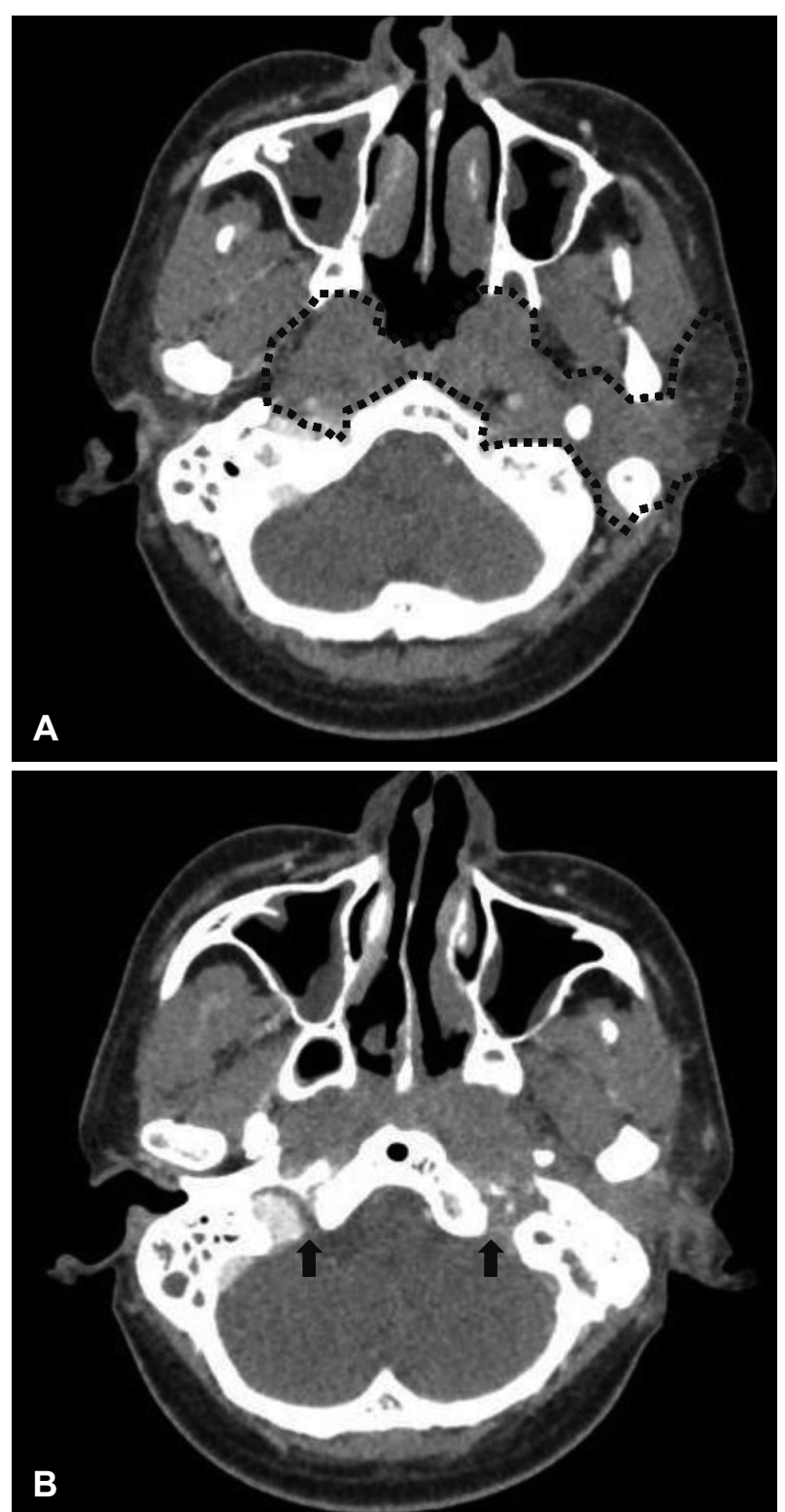

Fig. 3. Radiologic findings. Axial view of neck computer tomography shows that diffuse infiltrative thickening in both the nasopharynx, parapharyngeal space, left parotid gland, left skull base and both cervical internal carotid artery (black dot-line) (A), and low-attenuation in left jugular foramen is showing comparing to right jugular foramen because of diffuse infiltrative lesion (black arrows) (B). 
해 조직검사가 비교적 쉬운 이하선과 비인두에서 조직검사를 시행하기로 하였다. 이하선에서 시행한 세침 흡인 세포 검사 는 세포 충실성이 낮았고 악성 소견은 나오지 않았다. 비인두 에서 시행한 펀치 생검에서 비정형 림프구들이 정상 구조를 파괴하는 모습이 관찰되었고, 비인두 상피 내에 림프구가 침

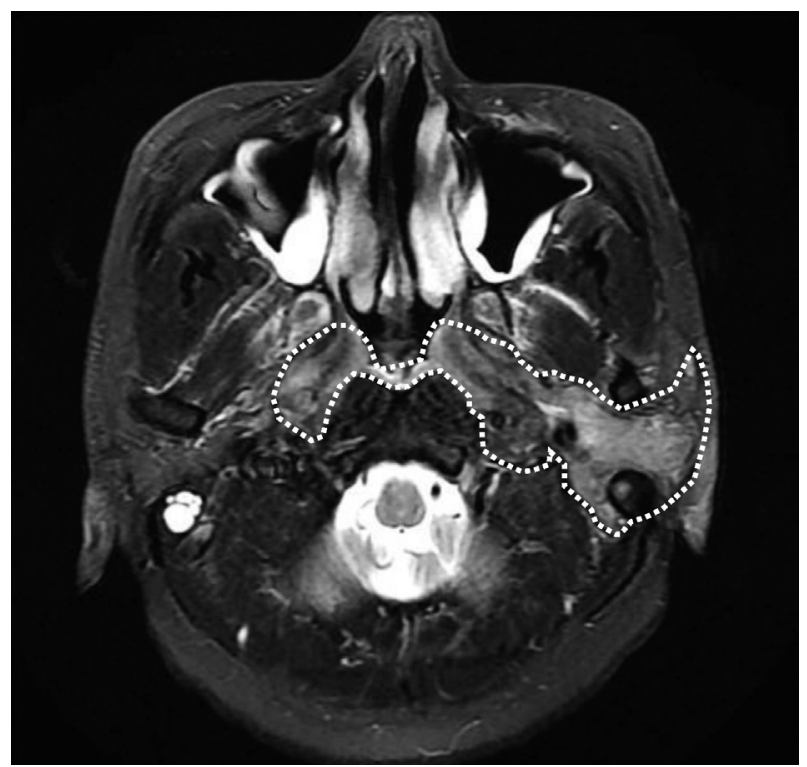

Fig. 4. Radiologic findings. Axial view of T2-weighted image brain MRI scan shows that diffuse infiltrative homogeneous thickening in both the nasopharynx, parapharyngeal space, left parotid gland, left skull base and both cervical internal carotid artery (white dot-line).
윤하는 lymphoepithelial lesion이 다수 관찰되었다. 면역조직 화학염색에서 $\mathrm{B}$-세포 표지자인 CD20에 양성을 보였고 $\mathrm{BCL} 2$ 에 양성, BCL6에 음성을 보여 점막 연관성 림프종으로 진단되었다(Fig. 5). 병기 설정을 위하여 양전자 컴퓨터 단층 촬영을 시행하였고 비강, 좌측 비인두, 이하선, 두경부 림프절, 간 실질에 대사의 증강이 보였다. MALT 림프종 진단하에 rituximab, cyclophosphamide, vincristine, prednisolone을 사용한 복합 항암 화학 치료를 6개월에 걸쳐 8회 시행하였다. 1 차 항암 치료를 마쳤을 때 목소리와 성대 움직임이 약간 호 전되고 있었고, 항암 치료 3 차를 마쳤을 때는 성대 움직임의 $2 / 3$ 이상이 회복되었다. 4차 후에는 성대움직임과 목소리가 완전 회복되었다(Fig. 6). 5차 항암 치료 종료 시에는 안면마 비가 3단계, 6차 종료 시에는 2단계로 호전되었다. 추적 관찰 로 시행한 목 전산화단층촬영상 양쪽 비인두, 경정맥공을 포 함한 좌측 뇌 기저부의 림프종의 광범위한 침윤은 호전된 소 견을 보였다(Fig. 7). 환자는 항암 치료 종료 후 8개월째 무병 상태로 경과 관찰 중이다.

\section{고 찰}

MALT 림프종은 B-세포에서 기원하는 저등급의 비호지킨 림프종의 아형으로, 결절 외 림프종(extranodal lymphoma)에 속해 있다. 소화기계 계통에 흔히 발생하며, 호흡기계, 피부, 또
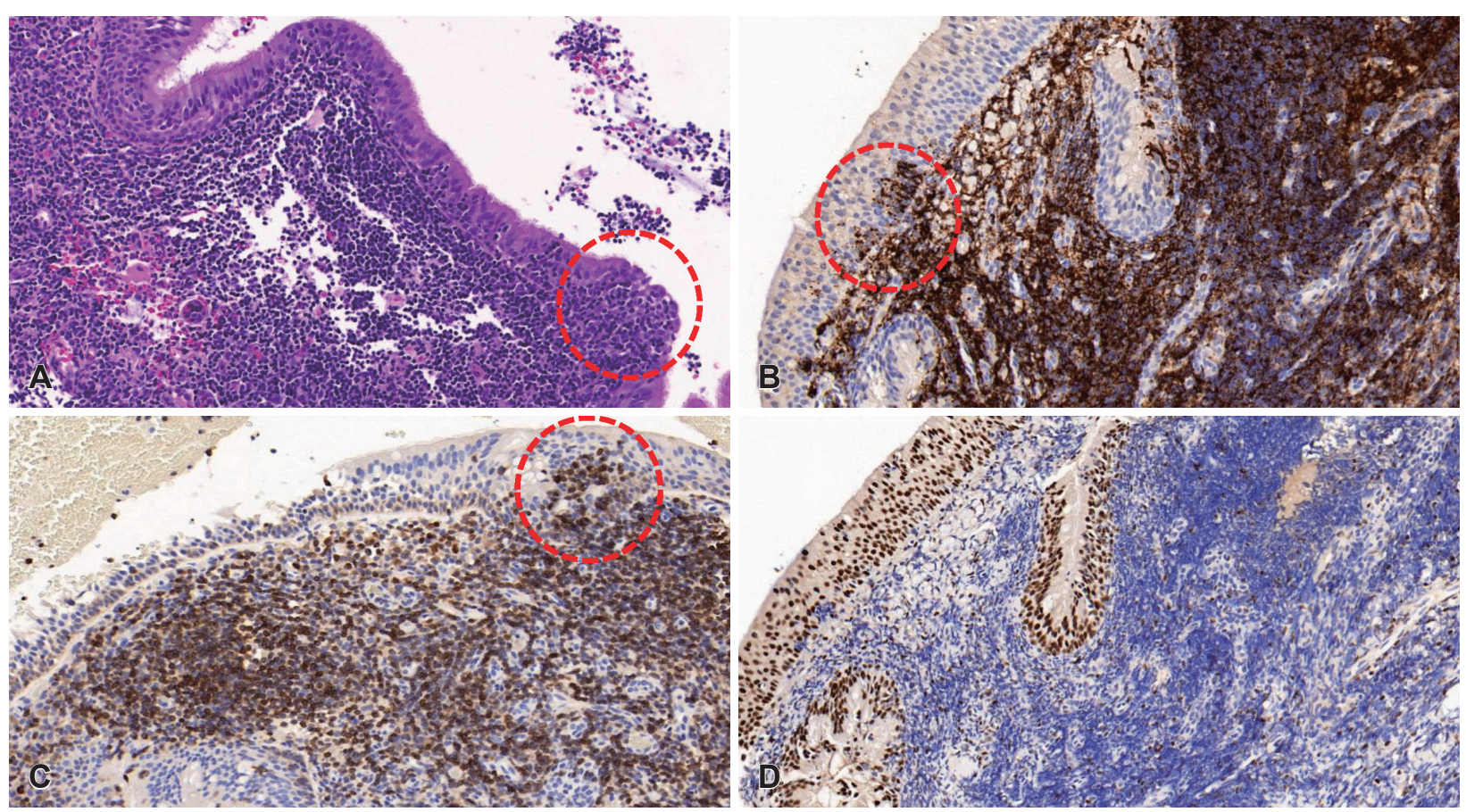

Fig. 5. Pathological findings. Normal nasopharyngeal architecture is effaced by atypical lymphoid cells. Tumor cells invade epithelial structures to form lymphoepithelial lesions (dot-lined circles) (hematoxylin and eosin staining, $\times 100)(A)$. Tumor cells show strong immunoreactivity for B-cell marker; CD20 (×100) (B). Positive staining for BCL2 $(\times 100)(C)$. No immunoreactivity for BCL6 $(\times 100)(D)$. 

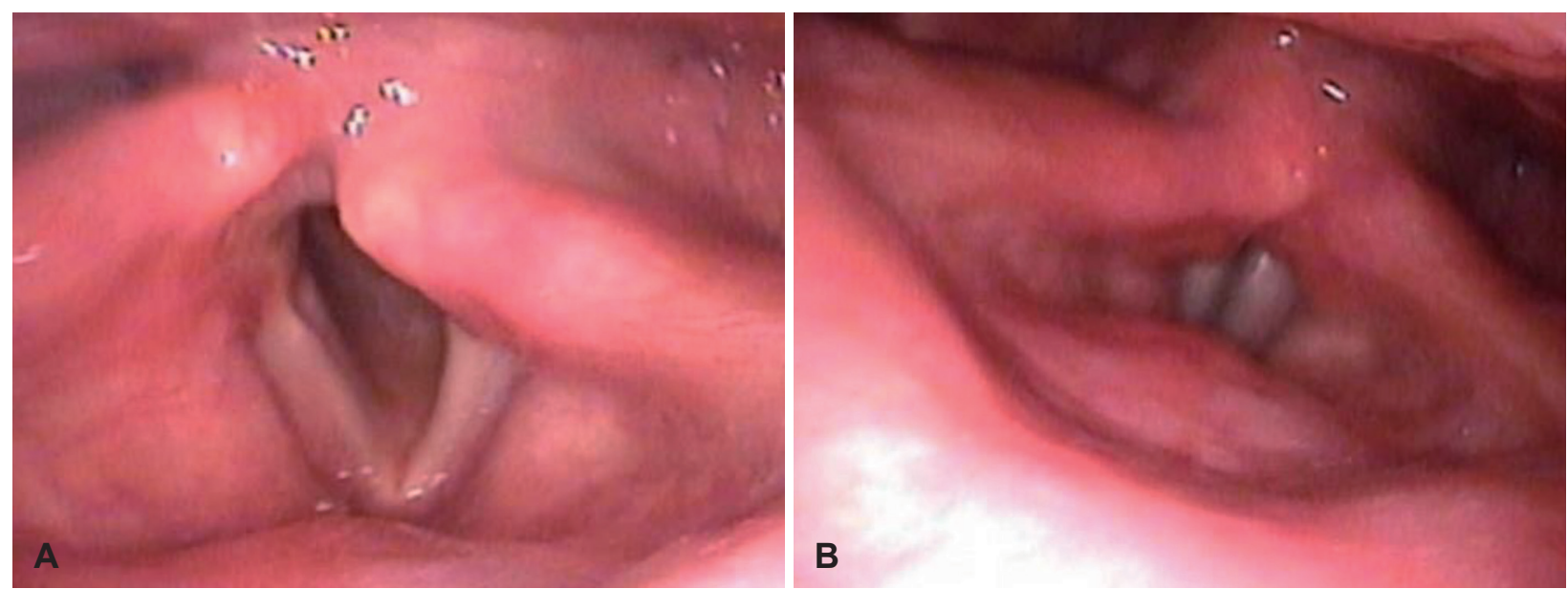

Fig. 6. Laryngoscopic examination shows that left vocal fold movement was fully recovered after chemotherapy inspiration (A), expiration (B).
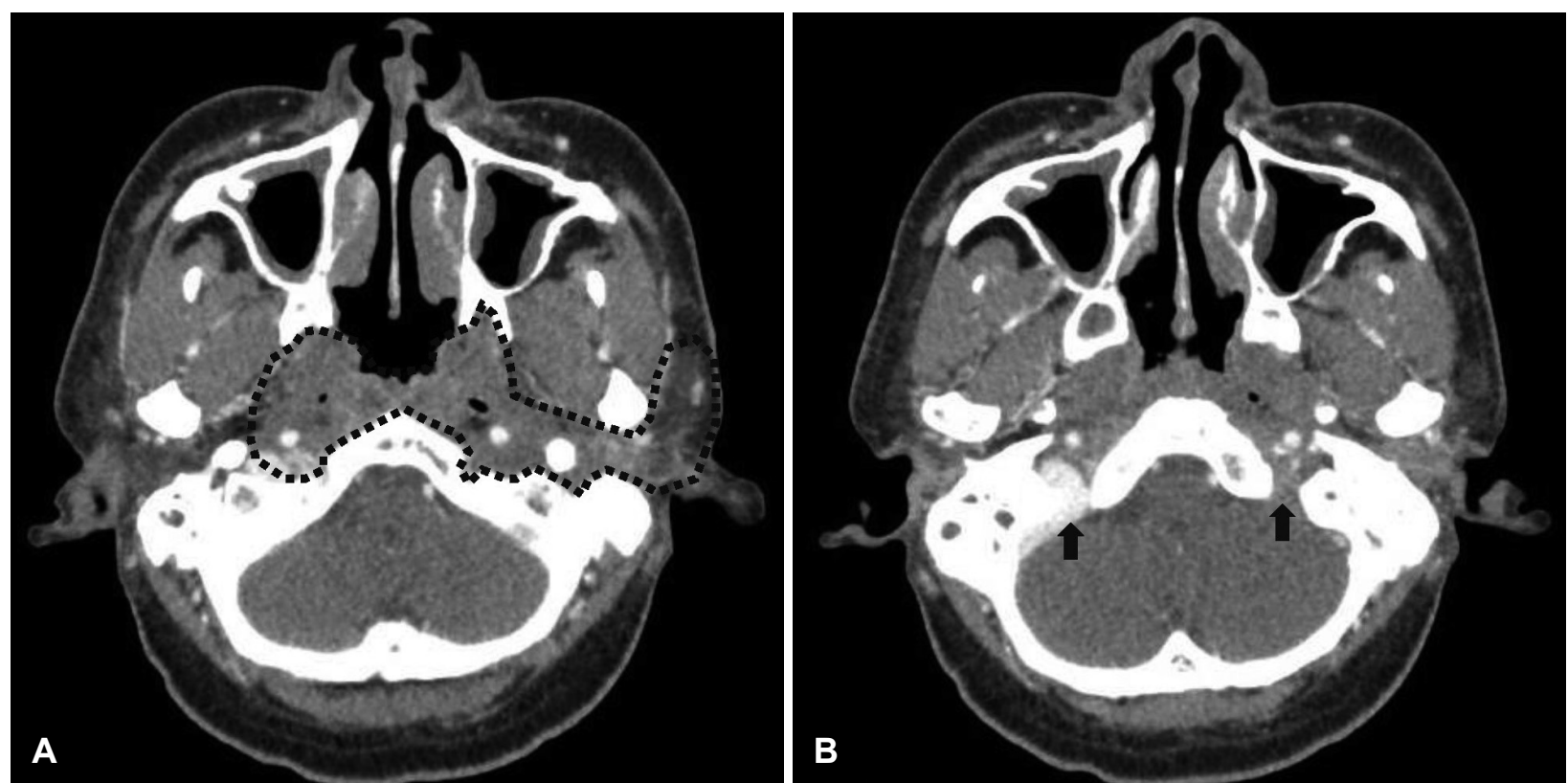

Fig. 7. Radiologic findings. After 6 cycles of chemotherapy, axial view of neck computer tomography shows that marked improved state of diffuse infiltrative lymphoma involvement (black dot-line) (A), and high-attenuation in left jugular foramen is showing comparing to initial neck computer tomography (black arrows) (B).

는 림프조직이 있는 장기에서 잘 호발한다. ${ }^{1)}$ Isaacson과 Wright" ${ }^{4}$ 가 MALT 림프종에 대해 1983년에 처음 보고하였다. 1994년 revised European-American lymphoma classification에서 림프종의 아형으로 포함되었다. 최근 $\mathrm{WHO}$ 분류에 서는 비호지킨 림프종의 한 분류로 정리되어 있다. ${ }^{5)}$ 두경부 영 역에서의 결절 외 림프종의 발생은 위장 관계에 이어 두 번째 이며, 대략 전체 결절 외 림프종 발생 중 $1 / 3$ 정도를 나타내고, 두경부 악성 종양의 12 15\%를 차지한다.) 이는 두경부 영역 이 외부에서 항원을 받아들이는 관문 역할역 수행하고, 항염 증 작용 및 감염이 자주 호발하기 때문으로 생각된다.” 만성적 인 염증을 유발하는 감염뿐만 아니라 하시모토 갑상선염 (Hashimoto's thyroiditis)이나 쇼그렌 증후군(Sjogren's syn- drome)과 같은 자가면역질환이 지속된다면 염증반응로 인해 림프구의 축적이 발생하여 MALT 림프종의 원인이 되기도 한 다. ${ }^{1-3)}$ 세균이나 바이러스의 만성감염도 림프종 호발에 영향을 미치는데, 위에서는 위나선균(Helicobacter pylori) 의 만성감 염이 림프종 호발에 영향을 미친다고 하며, 엡스타인바 바이 러스, C형 간염 바이러스, 제6, 8형 사람 헤르페스 바이러스나 사람면역결핍바이러스 감염도 이하선의 림프종 호발에 영향 을 미친다. ${ }^{8)}$

두경부 영역에서 MALT 림프종은 장시간 동안 발생한 부 위 점막에 국한되는 경향이 있어, 증상 발생은 느리다고 알 려져 있으며, 다른 림프종에 비해 예후가 좋다.9) 비인두를 침 범한 경우 일반적인 부비동염의 증상을 따르며, 눈물관의 폐 
쇄를 나타내기도 한다고 알려져 있다. ${ }^{10)}$ MALT 림프종은 보 통 오랜 시간 동안 특정 부위에만 존재한다고 알려져 있다. ${ }^{11)}$ 하지만 주위로 파급이 드물지 않아, 여러 부위를 침범하기도 한다. 환자의 $1 / 3$ 정도는 여러 점막의 침범을 겪는다고 한 다. ${ }^{9}$ 본 사례에서는 두경부에서 발생한 MALT 림프종이 파 급되어 두개저까지 침범하면서 경정맥공을 지나는 뇌신경 제 10 번에 마비가 생기면서 성대마비가 동반된 것으로 추정된 다. 림프종이 신경계에서 직접 호발하는 경우도 존재하고, ${ }^{12)}$ 비인두에서 발생한 MALT 림프종에 대한 보고도 드물게 있 지만, ${ }^{2)}$ 비인두와 이하선을 포함하여 뇌 기저부에 이르기까지 넓은 두경부 영역에서 MALT 림프종이 파급되어 안면신경 마비를 일으키고, 경정맥공까지 침범하여 후두마비를 일으 키는 예는 보고된 바가 없다.

MALT 림프종의 진단을 위해서 전산화단층촬영이나 자기 공명영상으로 병변의 크기나 모양, 위치, 침윤 범위를 파악할 수 있는 의의가 있다. 양전자방출단층촬영도 진단에 도움이 되며, 병기 설정 및 치료 방침, 예후를 파악하는 데 도움이 된 다. ${ }^{13)}$ 확진검사를 위해서는 조직검사가 필수적이며, 비정형 림 프구가 림프절 외 침범 소견을 보인다. 이는 만성 감염과 혼동 될 수 있어, 면역조직화학염색같은 추가적인 진단 방법을 동반 해야 한다. ${ }^{22}$ 이하선 종물에서는 세침 흡인 검사를 시행해 볼 수 있다. 세침 흡인 검사에서 악성종양이 나타나지 않더라도 임상적으로 악성 종양 등이 의심된다면, 중심부 바늘생검과 같이 민감도와 특이도가 높은 검사를 시행해 볼 수 있으며, ${ }^{14)}$ 이하선 절제술과 같은 수술적인 방법으로 진단을 할 수도 있 다. ${ }^{13)}$ 본 증례에서는 빠른 진단을 위해서 이하선의 세침 흡인 검사를 시행하였고, 그리고 세침 흡인 검사에서 만족스러운 결과가 나오지 않을 가능성 등을 염두해두고 동시에 비인두 조직에서도 조직검사를 시행하여 빠른 진단을 할 수 있었다.

MALT 림프종과 같은 저등급의 림프종은, 성장속도가 느리 고 임상양상 역시 길게 나타난다. 병기는 Ann Arbor staging으 로 분류되며 I-II 단계의 조기암과 III-IV 단계의 진행함으로 분류한다. 모든 단계의 MALT 림프종에서는 항암치료를 고려 할 수 있으며, I-II 단계의 국한된 림프종에서는 방사선 치료를 일차적으로 사용할 수 있고 방사선 치료와 더불어 절제술 역시 도움이 된다. 진행된 림프종에서는 rituximab과 cyclophosphamide, adriamycin, vincristine, prednisone을 사용하는 R$\mathrm{CHOP}$ 항암요법과 더불어 방사선 치료를 시행한다. ${ }^{15}$

본 증례에서는 성인에서 영상검사상 이하선 또는 비인두 등에서 침윤성의 경계가 불명한 조영증강을 보였다. 침윤성으 로 경계가 불분명한 경우는 전형적인 두경부 종양의 특징을 시사하지는 않지만, 지속되는 통증을 동반한 이하선 비대와 안면마비, 삼출성 중이염, 수개월 후 동반된 성대 마비의 증상
들은 드물지만 MALT 림포종 등의 비전형적인 영상학적 소 견을 보이는 악종의 가능성을 의심해야 한다. 진단을 위해 다 각적으로 그리고 적극적으로 조직검사를 시행해야 한다. 환자 는 비인두 조직검사에서 림프종을 확진하게 되었고 환자는 항암치료 후 안면과 후두 신경마비가 대부분 회복되었다.

\section{Acknowledgments}

None.

\section{ORCID}

Dong Kun Lee https://orcid.org/0000-0002-7296-1420

\section{REFERENCES}

1) Thieblemont C, Berger F, Dumontet C, Moullet I, Bouafia F, Felman P, et al. Mucosa-associated lymphoid tissue lymphoma is a disseminated disease in one third of 158 patients analyzed. Blood 2000;95(3):802-6.

2) Mehle ME, Kraus DH, Wood BG, Tubbs R, Tucker HM, Lavertu P. Lymphoma of the parotid gland. Laryngoscope 1993;103(1):17-21.

3) Anacak Y, Miller RC, Constantinou N, Mamusa AM, Epelbaum R, Li Y, et al. Primary mucosa-associated lymphoid tissue lymphoma of the salivary glands: A multicenter Rare Cancer Network study. Int J Radiat Oncol Biol Phys 2012;82(1):315-20.

4) Isaacson P, Wright DH. Malignant lymphoma of mucosaassociated lymphoid tissue. A distinctive type of B-cell lymphoma. Cancer 1983;52(8):1410-6.

5) Vardiman JW, Harris NL, Brunning RD. The World Health Organization (WHO) classification of the myeloid neoplasms. Blood 2002;100(7):2292-302.

6) Vega F, Lin P, Medeiros LJ. Extranodal lymphomas of the head and neck. Ann Diagn Pathol 2005;9(6):340-50.

7) Thakral B, Zhou J, Medeiros LJ. Extranodal hematopoietic neoplasms and mimics in the head and neck: An update. Hum Pathol 2015;46(8):1079-100.

8) Aydın S, Demir MG, Barışık NÖ. Extranodal marginal zone lymphoma of the parotid gland. J Maxillofac Oral Surg 2016; 15(Suppl 2):346-50.

9) Zucca E, Bertoni F. The spectrum of MALT lymphoma at different sites: Biological and therapeutic relevance. Blood 2016;127(17): 2082-92.

10) Shin MS, Lim SC. Mucosa-associated lymphoid tissue lymphoma arising from the nasal mucosa: A case report and review of the literature. Korean J Otolaryngol 2006;49(12):1227-30.

11) Kalpadakis C, Pangalis GA, Vassilakopoulos TP, Kyriakaki S, Yiakoumis X, Sachanas S, et al. Clinical aspects of malt lymphomas. Curr Hematol Malig Rep 2014;9(3):262-72.

12) Park WS, Ko SH, Yoo BJ, Chung JH. A Case of MucosaAssociated Lymphoid Tissue Lymphoma in Nasopharynx and Thyroid Gland. Korean J Otolaryngol-Head Neck Surg 2017; 60(11):579-83.

13) Zapater E, Bagán JV, Carbonell F, Basterra J. Malignant lymphoma of the head and neck. Oral Dis 2010;16(2):119-28.

14) Zbären P, Triantafyllou A, Devaney KO, Poorten VV, Hellquist H, Rinaldo A, et al. Preoperative diagnostic of parotid gland neoplasms: Fine-needle aspiration cytology or core needle biopsy? Eur Arch Otorhinolaryngol 2018;275(11):2609-13.

15) Dreyling M, Thieblemont C, Gallamini A, Arcaini L, Campo E, Hermine O, et al. ESMO Consensus conferences: Guidelines on malignant lymphoma. Part 2: Marginal zone lymphoma, mantle cell lymphoma, peripheral T-cell lymphoma. Ann Oncol 2013; 24(4):857-77. 